\title{
Quality of life of older adults admitted to a Medical Clinic Unit of a Public Hospital in Brazil
}

\author{
Qualidade de vida de idosos internados em uma Unidade \\ de Clínica Médica de um hospital público \\ Calidad de vida de pacientes ancianos ingresados en una \\ Unidad de Clínica Médica de un hospital público
}

How to cite this article:

Martins NPR, Silqueira SMF, Souza LME, Souza CPM, Soares SM, Matos SS. Quality of life of older adults admitted to a Medical Clinic Unit of a Public Hospital in Brazil. Rev Esc Enferm USP. 2020;54:e03573. doi: https://doi.org/10.1590/S1980-220X2018032903573

\author{
Núbia Pires da Rocha Martins ${ }^{1}$ \\ Salete Maria de Fátima Silqueira² \\ Lívia Maria Emerick Souza ${ }^{1}$ \\ Carine de Paula Martins Souza ${ }^{1}$ \\ Sônia Maria Soares ${ }^{2}$ \\ Selme Silqueira Matos ${ }^{2}$ \\ ${ }^{1}$ Universidade Federal de Minas Gerais, \\ Hospital das Clínicas, Programa de \\ Residência Multiprofissional em Saúde \\ do Idoso, Belo Horizonte, MG, Brazil. \\ ${ }^{2}$ Universidade Federal de Minas Gerais, Escola \\ de Enfermagem, Belo Horizonte, MG, Brazil.
}

\begin{abstract}
Objective: To evaluate the quality of life of older adults admitted to the Medical Clinic Unit of a public hospital in Belo Horizonte, Brazil, to correlate the quality of life with the functionality proposed by the Katz index, and to characterize the clinical and epidemiological profile of the studied population. Method: This is a descriptive crosssectional study with a quantitative approach. Data collection was performed through applying the Nottingham Health Profile instrument and the Katz Index instrument. Results: 116 older adults participated. The quality of life found in the study was considered good. It correlated with the Katz index (the more dependent, the worse the quality of life), the number of comorbidities (the higher the number of comorbidities, the worse the quality of life) and the family structure who lived with the older adults (there was worse quality of life for older adults who lived with their children). Conclusion: In this study it was found that the quality of life in the evaluated sample was good and that it is related to functionality, the number of comorbidities and with whom the older adult lives. Thus, poor quality of life cannot be associated with hospitalization in this sample.
\end{abstract}

\section{DESCRIPTORS}

Aged; Hospitalization; Quality of Life; Health of the Elderly; Geriatric Nursing. 


\section{INTRODUCTION}

Population aging is a reality in developing countries. It is estimated that Brazil will be the sixth oldest country in the world by 2025 , with an average of 32 million older adults ${ }^{(1)}$. This demographic reality implies changes in morbidity, mortality and health in the country, requiring sufficient policies, programs and human resources to meet the specific needs of this population group ${ }^{(2)}$.

The preservation of Quality of Life (QoL) in old age is the main challenge imposed by longevity for older adults, since it is a process that encompasses wide complexity, i.e. it is determined and influenced by several factors such as: biological health, mental health, satisfaction, cognitive effectiveness, social status, income, continuity of occupational bonds, and roles of family and friends. Thus, the Ministry of Health instituted the National Health Policy for Older Adults in 2006, which states the promotion of QoL, preservation of autonomy and functional independence of older adults at any level of health care as its goal and guideline ${ }^{(3-4)}$. Therefore, establishing comprehensive health programs is essential so that strategies to achieve this goal are promoted.

It is known that older adults are subject to increased incidence of chronic degenerative diseases which enhances the functional loss of organs, resulting in functional limitations and disabilities. Added to this reality, there is a greater predisposition of older adults to physical limitations, cognitive decline, sensory loss, depressive symptoms, falls and social isolation, enhancing their functional impairment and contributing to their dependence for basic and instrumental activities of daily living. As a consequence, negative repercussions on QoL of this population will be observed ${ }^{(5-6)}$.

Considering the above, it can be stated that older adults use hospital services more intensely when compared to other age groups, causing higher costs, longer hospitalization and slower and more complicated recovery ${ }^{(7)}$.

Hospitalization is a risk for older adults, as it results in a reduction in functionality and changes in QoL, which often becomes irreparable $\mathrm{e}^{(7-8)}$. Hospitalization is a complex event that occurs in a moment of fragility, in which older adults are removed from their family and social environment and placed in a strange environment in which the routine differs from their daily life. This results in a loss of autonomy and functional dependence which can become permanent, thus affecting their QoL ${ }^{(7)}$.

Considering that the loss in QoL and functionality during hospitalization will cause adverse events during this period and may be reflected in the health of older adults after hospital discharge, the findings of the present study will be used to elaborate strategies and plans aimed at minimizing the impact of hospitalization on their lives; moreover, these results will enrich the literature on the subject within the scope of Gerontology.

Therefore, this study aims to evaluate the Quality of Life of older adults on the Seventh-floor of a public hospital Medical Clinic Unit in Belo Horizonte, Brazil, with the specific objectives to correlate the quality of life with functionality proposed by the Katz index and to characterize the clinical and epidemiological profile of the studied population.

\section{METHOD}

\section{StUdDY DESIGN}

This is a descriptive cross-sectional study with a quantitative approach.

\section{SCENARIO}

The study was conducted on the seventh floor of the medical clinic unit of a large public hospital in Belo Horizonte. This sector is part of the Medical Clinic functional unit, as well as the $10^{\text {th }}$ floor (East wing), the Adult Intensive Care Unit (ICU) and an Outpatient Clinic. The study unit has 63 beds for patients requiring care at minimum to semi-intensive levels, with predominantly intermediate-level patients of various clinical subspecialties.

\section{SELECTION CRITERIA}

Older adults aged 60 years and over and who were hospitalized on the seventh floor for at least 24 hours were included in the study, while older adults with a score equal to or lower than 8 according to the Glasgow Coma Scale, older adults with Delirium and older adults with aphasia were excluded, as described in the medical record by the multidisciplinary or medical team. Thus, the final sample consisted of 116 older adults.

The Glasgow scale is used worldwide to define the level of consciousness and identify neurological dysfunctions based on numerical parameters ranging from 3 to 15 , and patients with a score of 8 or less are considered to be in a coma and were therefore excluded from this study ${ }^{(9)}$.

\section{Data collection}

Study data were collected only once through individual application of the Nottingham Health Profile (NHP) instrument and the Katz Index. These questionnaires were applied by two trained examiners in order to reduce errors in interpreting the questions, which would affect the reliability of the results. This data was collected during weekdays from December 2013 to March 2014.

The NHP is a generic instrument developed in 1975 at the Department of Community Health at the University of Nottingham ${ }^{(10)}$ to assess QoL. It was translated and adapted for use in Brazil in 2004(11). It consists of 38 questions which are based on the WHO International Classification of Functioning, with dichotomous answers (yes/no format). The questions are divided into six domains, namely energy level, pain, emotional reactions, sleep, social interaction and physical abilities. Thus, it assesses the physical, emotional and social health of the individual. Each negative answer is scored 0 points and each positive answer is assigned 1 point, making 38 points at the end. The lower the score, the better the older adult's QoL ${ }^{(11)}$. 
The NHP was originally developed for patients with chronic disease and has a high rate of clinical validity in this population. Its internal consistency varies between 0.90 and 0.94 and its test-retest reliability is good ( $r=0.75$ to 0.88$)$. However, in a study which aimed to evaluate the psychometric properties of the adapted version of this instrument in older adult patients, patients with hemiplegia, and patients with Parkinson's disease in one community, one concluded that the instrument had problems in clinical validity for the studied sample. Thus, the authors state that this instrument would have better clinical validity if applied to more debilitated or hospitalized patients, since the population they studied had a reasonable level of functional independence ${ }^{(11-12)}$.

The Katz Index was used to evaluate the functionality of older adult inpatients, aiming to increase the sensitivity and clinical validity of the NHP. This instrument was proposed by Katz in $1963^{(13)}$ and assesses the degree of dependence of older adults for Basic Activities of Daily Living (ADLs). It was adapted to the Brazilian culture in $2008^{(14)}$. The evaluated activities are: bathing, dressing, toileting, transferring, continence and feeding. In this study, the older adults were classified as dependent, independent and partially independent. A score was assigned to each older adult in order to classify them according to their dependence on Katz activities, i.e. the older adults who were independent in performing the task received 0 points and those who had dependence received a point. Thus, individuals who achieved a final score of zero points were classified as independent, those who achieved a score of six as totally dependent, and those who scored from one to five as partially dependent ${ }^{(13-14)}$.

The Glasgow Coma Scale was applied prior to the NHP and Katz Index questionnaires in order to assess the level of consciousness. It is based on an evaluation of three parameters, namely: eye opening, verbal response and motor reaction. Scores on this scale range from 3 to 15 , with a score less than or equal to 8 denoting severe impairment of consciousness and coma, requiring an alternative airway ${ }^{(9)}$.

\section{DATA ANALYSIS AND PROCESSING}

Statistical analysis was performed using the Statistical Package for Social Sciences program (SPSS 15.0). The Katz Index and NHP were analyzed by domains and median values were additionally presented. QoL was defined as the dependent variable and the other study variables as independent. A Biserial test and Spearman correlation (rho) were performed to evaluate bivariate associations between the Katz index and sociodemographic variables, to verify the associations between the NHP and these variables, and to verify the association between the NHP and the Katz index. Multiple linear regression analysis was also performed to find the determining factors and how much they contributed to the total NHP score. The significance level considered was $\mathrm{p}<0.05$. The results are presented in tables and figures.

\section{ETHICAL ASPECTS}

This study was approved by the Ethics and Research Committee (COEP) of the Universidade Federal de
Minas Gerais in December 2013, with approval number 21389213.1.00005149. This study was also approved by the Management of the Medical Clinic Unit of the Hospital in which it was conducted and by the Teaching, Research and Extension Directorate $(D E P E)$. Patients and their guardians were provided with information on the study and were requested to sign the Informed Consent Form in two copies. The form informed participants and family members or caregivers about the research theme and objectives, guaranteed assured anonymity and the treatment and use of data only for research purposes, dissemination in scientific events and publications, with their identities kept confidential in any other situations. Thus, this study is in accordance with the National Health Council Resolution 466/2012 ${ }^{(15)}$.

\section{RESULTS}

There were 199 older adults admitted to the study sector in the period defined for data collection, of which 116 were included in the present study, and 63 (54.3\%) were women. The median age of the older adults was 69.5 years (64-76). Regarding marital status, the vast majority of the older adults were married (65 or 56\%); however, $12(10.3 \%)$ were single, 12 (10.3\%) divorced and 27 (23.3\%) were widowers.

Regarding their education, there was a prevalence of older adults who did not complete elementary school, with a number of 55 older adults (47.4\%), while illiteracy was present in 39 of the older adults being equivalent to $33.6 \%$ of the sample. However, one $(0.9 \%)$ older adult had completed higher education, 10 (8.6\%) had completed elementary school, and six (5.2\%) had completed high school.

Regarding the family life variable, it was found that 32 $(27.6 \%)$ of the older adults lived with their children, 32 (27.6\%) with their spouse, 14 (12.1\%) lived alone and 38 lived with their families, with the spouse plus another person who had some degree of kinship being considered family in this study.

The health problems which motivated the older adults to seek hospital care were grouped into the following large groups: cardiovascular (responsible for $53.4 \%$ of the hospitalized older adults), neurological (18\%), ophthalmic (2\%), cancer (5\%), renal (2\%), infection (10\%), gastrointestinal (3\%), respiratory (5\%) and muscle worsening (1.6\%). Regarding the clinical profile of these patients, it was evident that most of the older adults $(36-31 \%)$ had two morbidities, $14(12.1 \%)$ older adults had four or more comorbidities, 27 (23.3\%) had three, 29 (25\%) had only one, and 10 (8.6\%) older adults had no diagnosis of any morbidity.

Regarding the financial income of the older adults, it was found that $58(50 \%)$ survived on a minimum monthly salary ( $\mathrm{R} \$ 724.00 /$ month (BRL)), 24 older adults received two minimum salaries, eight earned three minimum salaries, 21 older adults received four or more minimum salaries, and five had no income of their own, so they were financially dependent on a family member with whom they lived.

Regarding the functional capacity assessed by the Katz Index, it was evidenced that 40 older adults (34.5\%) were independent, 56 (48.8\%) were partially dependent and $20(17.2 \%)$ were totally dependent. Table 1 describes the 
functionality according to each activity evaluated by the previously mentioned instrument.

Table 1 - Katz Index by domain - Belo Horizonte, MG, Brazil, 2013.

\begin{tabular}{lcc}
\hline Domains & Dependence & Independence \\
\hline Bathing & $67(57.8 \%)$ & $49(42.2 \%)$ \\
Dressing & $63(54.4 \%)$ & $53(45.7 \%)$ \\
Transferring & $55(47.4 \%)$ & $61(52.6 \%)$ \\
Toileting & $52(44.8 \%)$ & $64(55.2 \%)$ \\
Continence & $56(48.3 \%)$ & $60(51.7 \%)$ \\
Feeding & $21(18.1 \%)$ & $95(81.9 \%)$ \\
\hline
\end{tabular}

The QoL of the older adults in this study was calculated as a median. They obtained a median of $12(8.0-17.0)$. The description of QoL across NHP domains is shown in Table 2.

Table 2 - Nottingham Health Profile - Belo Horizonte, MG, Brazil, 2013.

\begin{tabular}{lc}
\hline Domains & QoL \\
\hline Energy level & $1.0(0.0-2.0)$ \\
Pain & $2.0(0.0-5.0)$ \\
Emotional reactions & $2.0(1.0-5.0)$ \\
Sleep & $2.0(0.0-3.0)$ \\
Social interaction & $1.0(0.0-2.0)$ \\
Physical abilities & $4.0(2.0-6.0)$ \\
\hline Total score & $\mathbf{1 2 . 0}(\mathbf{8 . 0}-\mathbf{1 7 . 0 )}$ \\
\hline
\end{tabular}

In correlating the general functionality score (Katz index) with QoL (NHP), it can be stated that both have a significant correlation (rho: 0.626; $\mathrm{p}<0.000$ ). Similarly, when the overall Katz index score is correlated with the functionality classification adopted in this study (dependent, partially dependent and fully dependent), a significant and strong correlation (rho: $0.945 ; \mathrm{p}<0.000$ ) is found between them.

It was possible to demonstrate that QoL has a moderate and therefore significant correlation with the Katz index domains through the Biserial test, as shown in Table 3. This means that dependence for some activity assessed by the Katz index is associated with worse QoL. It can be seen from the table data that all domains of the Katz index had a positive and moderate correlation with QoL, thus inferring that dependence in any domain leads to worse QoL in the hospital.

The QoL of the hospitalized older adults was significantly correlated with the variables of who they live with (rho: $0.312 ; \mathrm{p}=$ 0.004), total Katz index score (rho: 0.626; $p=0.000$ ), Katz index rating (rho: $0.616 ; p=0.000$ ), number of comorbidities (rho: $0.298 ; p=0.001$ ) and household income (rho: $-0.184 ; p=0.048$ ).

Based on the above data, a model consisting of three independent variables was created (Katz Classification, who they live with and number of comorbidities). Although age did not present a level of statistical significance with QoL (rho: 0.209; $\mathrm{p}<0.025$ ), it showed a significant correlation with functionality, meaning that the older the person, the more dependent they were (rho: $0.362 ; p=0.000$ ). Age did not enter the final model when performing multiple linear regression between these variables and overall QoL. The variables were chosen considering the largest association with the main variable (QoL), according to data from the model presented in Table 4.

Table 3 - Correlation between QoL and Katz Index domains - Belo Horizonte, MG, Brazil, 2013.

\begin{tabular}{|c|c|c|c|c|c|c|c|}
\hline & Total QoL & $\begin{array}{c}\text { Katz - } \\
\text { bathing }\end{array}$ & $\begin{array}{c}\text { Katz- } \\
\text { dressing }\end{array}$ & $\begin{array}{c}\text { Katz- } \\
\text { transferring }\end{array}$ & $\begin{array}{c}\text { Katz- } \\
\text { toileting }\end{array}$ & $\begin{array}{c}\text { Katz- } \\
\text { continence }\end{array}$ & $\begin{array}{l}\text { Katz- } \\
\text { feeding }\end{array}$ \\
\hline Biserial correlation & & 0.609 & 0.530 & 0.639 & 0.698 & 0.746 & 0.677 \\
\hline Sig. (2- tailed) & & 0.000 & 0.000 & 0.000 & 0.000 & 0.000 & 0.000 \\
\hline
\end{tabular}

Table 4 - Multiple linear regression - independent variables Katz Index Classification, who they live with and number of comorbidities - Belo Horizonte, MG, Brazil, 2013.

\begin{tabular}{lccc}
\hline Variables & Beta & Partial R & P-value \\
\hline Katz Classification & 0.519 & 0.545 & $<0.0001$ \\
Who they live with & -0.217 & -0.267 & 0.004 \\
Number of co-morbidities & 0.156 & 0.195 & 0.040 \\
\hline
\end{tabular}

Legend: Katz Index Classification: 0: independent; 1 to 5: partially dependent; 6: totally dependent.

Table 3 shows that the higher the Katz index rating, the higher the QoL score, meaning the more dependent the older adult, the worse their QoL in the hospital. The older adults who lived with their family had better QoL than the others (average: 10.11), while the older adults who lived with their children scored a worse QoL (average: 15.88). Interestingly, the study found that older adults living alone had better QoL than those living with their children (QoL $=15 ; 15.88$, respectively) (Figure 1 ).

Regarding the number of comorbidities, it was evident that the higher the number of comorbidities the older adult had, the worse their QoL (rho: 0.195).

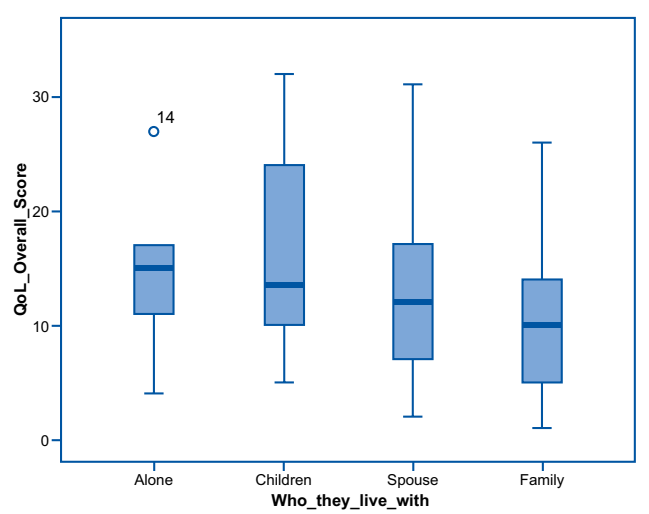

Figure 1 - Quality of life versus who they live with - Belo Horizonte, MG, Brazil, 2013. 


\section{DISCUSSION}

There was a slight predominance of female patients (54.3\%) in the study which may be justified by the predominance of women in the Brazilian population, which is due to the higher rate of male mortality throughout life ${ }^{(1)}$. The median found regarding age corroborates the results found in the literature ${ }^{(16-17)}$.

Regarding marital status, the data found in this study (56\% of married older adults) differ from the results of studies that have a sample of older adults ${ }^{(18)}$, since with increasing age there is an increased probability of one of the spouses dying.

Regarding education, there was a prevalence of older adults with low education, while illiteracy was present in $33.6 \%$ of the older adults in this sample. Low education is considered a risk factor for health implications and disability, as it is related to the socioeconomic level of the individual, thus directly related to living conditions, diet, and lifestyles ${ }^{(17)}$.

A low monthly income may affect the lives of older adults, considering that this individual has special needs to maintain their health, so low income may negatively influence their health and QoL. Income had a significant correlation with QoL ( $\mathrm{p}=0.048)$ in this study. Literature data show that low income among older adults is common ${ }^{(17-19)}$.

Family arrangement in Brazil is influenced by many factors such as economic, cultural, historical and others. Thus, the choice of family arrangement is not only of the older adult, but is a reflection of the factors mentioned above $\mathrm{e}^{(20)}$.

Family support is known to contribute to the physical and psychological integrity of older adults. However, just living with family or children does not indicate satisfactory family relationships, so it is necessary to assess how satisfied the older adult is with such relationships.

The data from this study showed that older adults who lived with their family had better QoL. This finding corroborates the result of a Polish study which assessed the differences in the quality of life of older adult rural residents according to family status, which showed that the group of older adults who lived with their families obtained a higher QoL score ${ }^{(21)}$. An intriguing and interesting result found by this study was that older adults who lived with their children had worse QoL compared to the others. It can be inferred that the type of social interaction that the older adult establishes with the family justifies this result, meaning that it is not enough to live with a family member, it is necessary to be satisfied with the relationship established between their family arrangement, as previously mentioned.

The aging of the Brazilian population highlights a reality which was unknown until recently, with chronic diseases being highlighted and occupying an important place in the health profile of the population. As a result, the main causes of hospitalizations are decompensated chronic degenerative diseases $^{(22)}$. The main causes of hospitalization among younger older adults (60-69 years old) in Brazil in 2018 were diseases related to the circulatory system $(289,982$ older adults), followed by respiratory diseases $(123,438$ older adults) and neoplasms (180,671 older adults). This is consistent with the data found in this study, which showed a higher number of hospitalizations for cardiovascular diseases (circulatory system diseases) $^{(23)}$.

As previously mentioned, there is an increased prevalence of chronic diseases due to aging, so it is not uncommon for older adults to have various types of diseases. Most of the older adults (n:36) in this study had two associated diseases, followed by 14 older adults who had three comorbidities. This prevalence of associated diseases that occurs with aging tends to compromise the QoL of older adults, generating disabling processes and affecting their functionality ${ }^{(17)}$.

There was a higher prevalence of partially dependent older adults (48.8\%) regarding functionality assessed by the Katz Index. Dependency is a dynamic process which can be modified, prevented or reduced. In this process, it is necessary to have qualified professionals committed to providing care for older adults. The prevalence of dependent older adults in a ward requires an adequate nursing team in both quantitative and qualitative terms, since the basic activities in which there is dependence will be performed by the team. The planning of actions should take into consideration the patient's stimulation to perform the possible activities, aiming to reduce the dependence and thus not make this process definitive so that the $\mathrm{QoL}$ is not negatively affected ${ }^{(7)}$.

However, the existence of conflict between managing and providing care is visible in the practice scenario, meaning nurses distance themselves from the direct care to the patient and dedicate themselves more to the management process, which results in poor quality care since caring and managing are inseparable. Thus, it can be stated that the quality of nursing care affects the quality of life and functionality of hospitalized older adults.

In this study it was found that functionality is related to QoL; the more dependent the older adult, the worse their QoL in the hospital, and being dependent regarding only one activity assessed by the Katz index is enough to reduce their QoL.

In a study aiming to estimate the prevalence of functional disability for daily basic and instrumental activities and associated factors in community-dwelling older adults, it was found that older adults hospitalized at least once in the last year had about $70 \%$ greater disability for basic activities ${ }^{(17)}$. Another study which verified the socioeconomic and clinical factors that contribute to the independence of long-lived older adults found that recent hospitalization is a factor responsible for limiting the functionality of these older adults. Thus, it can be stated that hospitalization negatively affects functionality and consequently the QoL of older adults ${ }^{(24)}$.

Functional disability limits the autonomy of older adults and reduces their QoL, because a satisfactory QoL for older adults can be understood as the possibility of being able to fulfill their basic daily functions properly, feeling good and living independently. Thus, it is possible to suggest that measures which promote functional independence lead to an improvement in $\mathrm{QoL}^{(7,17)}$. 
The score found by this study regarding QoL suggests that the hospitalized older adults had a good quality of life, since the lower the score found, the better the evaluated QoL ${ }^{(11)}$. However, the result was the opposite in a study conducted in Alagoas state, Brazil, with hospitalized patients with heart disease; the participating patients had a negative perception of QoL, but the statistically significant domains in the mentioned research were physical abilities, sleep, pain and emotional reactions ${ }^{(12)}$.

Gaps were found in the literature on the QoL of hospitalized older adults, which indicates the need for further studies on the subject in order to facilitate planning health care which reduces the impact of hospitalization on older adults' lives.

The study presents some limitations, such as non-specificity of the NHP for the hospitalized population; all the activities proposed by the instrument were not addressed, such as question 36 which comprises the act of climbing or descending stairs, as 48 older adult responded that they did not climb stairs in the hospital; question 19 which addresses pain when walking; 16 older adults said they had not walked up to the application period of the questionnaire; question 24, which addresses pain when standing up; 11 older adults reported not standing up until the NHP application day; question 14, which addresses the difficulty of bending over; 10 older adults said they could not bend over, so they do not perform this activity. These answers were scored 0 .
Another limitation of the study was that it did not assess the interference of the length of hospital stay, which may have a major influence on QoL. Therefore, it would be important to develop further studies that evaluate the interference of length of hospital stay and the cognition of older adult patients through the mini-mental state examination, since it was not applied in this study.

\section{CONCLUSION}

The study data show that the QoL of older adults admitted to the Medical Clinic Unit of a public hospital in Belo Horizonte is good and is related to their functionality, the number of comorbidities and who they live with. The correlation between QoL and functionality proposed by the Katz index was moderate and it was found that being dependent on any domain assessed by this scale is directly related to QoL, meaning that dependence worsens the QoL of the hospitalized older adults. The higher the number of comorbidities presented by the older adults, the worse their QOL was, while living with their children was also significantly worse for their quality of life when compared to living alone or with their family.

Knowing the QoL and its relation to the functionality of hospitalized older adults enables establishing a nursing care plan and strategies to prevent a reduction in functionality and consequently the loss of $\mathrm{QoL}$ of this population, as data suggest that a reduction in QoL can be prevented by preventing the loss of functionality.

\section{RESUMO}

Objetivo: Avaliar a Qualidade de Vida de idosos internados na Unidade de Clínica Médica de um Hospital Público de Belo Horizonte, correlacionar a qualidade de vida com a funcionalidade proposta pelo índice de Katz e caracterizar o perfil clínico e epidemiológico da população estudada. Método: Trata-se de um estudo descritivo, transversal, de abordagem quantitativa. A coleta de dados foi realizada por meio da aplicação do instrumento Perfil de Saúde de Nottingham e do instrumento Index de Katz. Resultados: Participaram 116 idosos. A qualidade de vida encontrada no estudo foi considerada boa. Ela teve correlação com o índice de Katz (quanto mais dependente, pior foi a qualidade vida), com o número de comorbidades (quanto maior o número de comorbidades, pior a qualidade de vida) e com a estrutura familiar que residia com o idoso (houve pior qualidade de vida em idosos que residiam com os filhos). Conclusão: A partir deste estudo constatou-se que na amostra avaliada a qualidade de vida foi boa e que está relacionada à funcionalidade, ao número de comorbidades e com quem o idoso reside. Dessa forma, não se pode associar à internação hospitalar uma qualidade de vida ruim nesta amostra.

\section{DESCRITORES}

Idoso; Hospitalização; Qualidade de Vida; Saúde do Idoso; Enfermagem Geriátrica.

\section{RESUMEN}

Objetivo: Evaluar la calidad de vida de ancianos internados en una unidad de clínica médica de un Hospital Público de Belo Horizonte, correlacionar la calidad de vida con funcionalidad propuesta por Katz y caracterizar el perfil clínico epidemiológico de la población. Método: Estúdio descriptivo, transversal, cuantitativo. Para la colecta de datos se utilizó el perfil de salud de Nottingham y Indice de Katz. Resultados: Participaron 116 ancianos. La calidad de vida fue considerada buena. Tuvo correlación con el Índice de Katz (cuanto más dependiente, peor la calidad de vida), con el número de comorbidades (cuanto más comorbidades, peor calidad de vida) y con la estrutura familiar que reside con el anciano (peor calidad de vida en idosos que vivían con los hijos). Conclusión: Se constató que la calidad de vida fue buena y está relacionada con la funcionalidad, número de comorbidades y con quién el anciano vive. Por eso no se puede associar a la internación hospitalar una calidad de vida mala, en este estúdio.

\section{DESCRIPTORES}

Anciano; Hospitalización; Calidad de Vida; Salud del Anciano; Enfermería Geriátrica.

\section{REFERENCES}

1. Instituto Brasileiro de Geografia e Estatística. Anuário Estatístico do Brasil: 2017 [Internet]. Rio de Janeiro: IBGE; 2018 [citado 2018 jul. 20]. Disponível em: https://biblioteca.ibge.gov.br/visualizacao/periodicos/20/aeb_2017.pdf

2. Miranda GMD, Mendes SCG, Silva, ALA. Public policies challenges on the background of demographic transition and social changes in Brazil. Interface (Botucatu). 2017;21:e0136. DOI: http://dx.doi.org/10.1590/1807-57622016.0136.

3. Pinheiro ODS, Aerosa SVC. A importância das políticas públicas para os idosos. Baru (Goiânia). 2018;4(2):184-93. DOI: http://dx.doi. org/10.18224/baru.v4i2.6724. 
4. Brasil, Ministério da Saúde. Portaria n. 2528 de 19 de outubro de 2006. Aprova a Política Nacional de Saúde da Pessoa Idosa [Internet]. Brasília; 2006 [citado 2019 abr. 26]. Disponível em http://bvsms.saude.gov.br/bvs/saudelegis/gm/2006/prt2528_19_10_2006.html.

5. Pinto Junior EP, Silva IT, Vilela ABA, Casotti, CA, Pinto FJM, Silva MGC. Dependência funcional e fatores associados em idosos corresidentes. Cad. Saúde Coletiva. 2016;24(4):404-12. DOI: http://dx.doi.org/10.1590/1414-462X201600040229.

6. Melo BRS, Diniz MAA, Casemiro FG, Figueiredo LC, Orlandi AAS, Hass VJ, et al. Cognitive and functional assessment about elderly people users of health public service. Esc Anna Nery. 2017; 21 :e0388. DOI: http://dx.doi.org/10.1590/2177-9465-ean-2016-0388.

7. Carvalho TC, Valle AP, Jacinto AF, Mayoral VF, Boas PJFV. Impact of hospitalization on the functional capacity of the elderly: a cohort study. Rev Bras Geriatr Gerontol. 2018; 21(2):e0143. DOI: http://dx.doi.org/10.1590/1981-22562018021.170143.

8. Mendonça MS, Souza-Muñoz R, Vieira ATP, Silva AEVF, Sales VCW, Moreira IF. Incapacidade para atividades da vida diária em pacientes idosos à admissão hospitalar e sua relação com evolução desfavorável. Rev Med Saúde (Brasilia) [Internet]. 2016 [citado 2019 abr. 30];5(1). Disponível em: https://portalrevistas.ucb.br/index.php/rmsbr/article/view/6769

9. Oliveira DMP, Pereira CU, Freitas ZMP. Scales for evaluating the level of consciousness in trauma brain injury and their relevance to nursing practices. Arq Bras Neurocir [Internet]. 2014 [cited 2018 July 20];33(1). Available from: http://files.bvs.br/upload/S/0103-5355/2014/ v33n1/a4284.pdf

10. Hunt SM, McEwen J, McKenna SP. Measuring health status: a new tool for clinicians and epidemiologists. J R Coll Gen Pract [Internet]. 1985 [cited 2019 Apr 30];35(273):185-8. Available from: https:/www.ncbi.nlm.nih.gov/pmc/articles/PMC1960139/

11. Teixeira-Salmela LF, Magalhães LC, Souza AC, Lima MC, Lima RCM, Goulart F. Adaptação do Perfil de Saúde de Nottingham: um instrumento simples de avaliação da qualidade de vida. Cad Saúde Pública. 2004;20(4):e0004. DOI: http://dx.doi.org/10.1590/S0102311 X2004000400004.

12. Santos JR, Reis SCCAG, Reis MCS, Soares ABAL, Jucá AL. Qualidade de vida de pacientes hospitalizados com doenças cardiovasculares: possibilidades de intervenção de terapia ocupacional. Rev Bras Ter Ocup. 2017;1(5):620-33.

13. Katz S, Ford AB, Moskowitz RW, Jackson BA, Jaffe MW. Studies of illness in the aged. The index of ADL: a standardized measure of biological ans psychosocial function. JAMA. 1963;185:914-9.

14. Lino VTS, Pereira SEM, Camacho LAB, Ribeiro Filho ST, Buksman S. Adaptação transcultural da Escala de Independência em Atividades da Vida Diária (Escala de Katz). Cad Saúde Pública. 2008;24(4):103-12. DOI: http://dx.doi.org/10.1590/S0102-311X2008000100010

15. Brasil. Ministério da Saúde; Conselho Nacional de Saúde. Resolução n. 466, de 12 de Dezembro de 2012. Dispõe sobre diretrizes e normas regulamentadoras de pesquisas envolvendo seres humanos [Internet]. Brasília; 2012 [citado 2018 jul. 24]. Disponível em: http:// bvsms.saude.gov.br/bvs/saudelegis/cns/2013/res0466_12_12_2012.html

16. Pereira EEB, Souza ABF, Carneiro SR, Sarges ESNF. Funcionalidade global de idosos hospitalizados . Rev Bras Geriatr Gerontol. 2014; 17(1):165-76. DOI: http://dx.doi.org/10.1590/S1809-98232014000100016.

17. Nunes JDN, Saes MO, Nunes BP, Siqueira FCV, Soares DC, Fassa MEG, et al. Functional disability indicators and associated factors in the elderly: a population-based study in Bagé, Rio Grande do Sul, Brazil. Epidemiol Serv Saúde. 2017;26(2):295-304.. DOI: http://dx.doi. org/10.5123/s1679-49742017000200007

18. Veiga B, Pereira RAB, Pereira AMV, Nickel R. Evaluation of functionality and disability of older elderly outpatients using the WHODAS 2.0. Rev Bras Geriatr Gerontol. 2016; 19(6):1015-21. DOI: http://dx.doi.org/10.1590/1981-22562016019.150053

19. Lage JSS, Okuno MFP, Campanharo CRV, Lopes MCBT, Batista RSA. Capacidade funcional e perfil do idoso internado no serviço de emergência. Rev Min Enferm. 2014;18(4):e0063. DOI: http://www.dx.doi.org/10.5935/1415-2762.20140063

20. Melo NCV, Teixeira KMD, Barbosa TL, Montoya AJ, Silveira. Household arrangements of elderly persons in Brazil: analyses based on the national household survey sample (2009). Rev Bras Geriatr Gerontol. 2016;19(1):139-51. DOI: http://dx.doi.org/10.1590/18099823.2016.15011

21. Chrusciel P, Szczekala KM, Derewiecki T, Jakubowska K, Nalepa D, Czekirda, ME, et al. Differences in the quality of life dependent on family status of the elderly living in rural areas - a cross-sectional survey. Ann Agric Environ Med. 2018; 25e3501. DOI: http://dx.doi. org/10.26444/aaem/93501.

22. Malta DC, Bernal RTI, Lima MG, Araújo SSC, Silva MMA, Freitas MIF, et al. Noncommunicable diseases and the use of health services: analysis of the National Health Survey in Brazil. Rev Saúde Pública. 2017;51 Suppl 1:4s. DOI: http://dx.doi.org/10.1590/s15188787.2017051000090.

23. Brasil. Ministério da Saúde. DATASUS. Informações de Saúde. Morbidade Hospitalar do SUS. 2018. Morbidade Hospitalar do SUS - por local de internação - Brasil, 2018 [internet]. Brasília; 2018 [citado 2019 maio 02]. Disponível em: http://tabnet.datasus.gov.br/cgi/tabcgi. exe?sih/cnv/niuf.def.

24. Ribeiro DKMN, Lenardt MH, Michel T, Setoguchi LS, Grden CRB, Oliveira ES. Contributory factors for the functional independence of oldest old. Rev Esc Enferm USP [Internet]. 2015 [cited 2019 May 02];49(1):89-96. Available from: http://www.scielo.br/scielo.php?script=sci_ar ttext\&pid=S0080-62342015000100089 